\title{
The Refederalization of American Health Care
}

\author{
Barry G. Rabe, Ph.D.*
}

The endurance of a significant federal government role in health care into the late $1980 \mathrm{~s}$ is remarkable, given the factors which seemed so likely to herald a new era of reduced central government involvement in health and countless other areas of domestic policy. Quite aside from the prospects for realignment and the overwhelming political success of a president with an abiding personal commitment to just such a "defederalization" strategy, spiraling health care costs and federal budget deficits seemed to augur not only a reduced role for the public sector in health care but, in particular, a reduced role for the central government. Health care was not a dominant issue in either the 1980 or 1984 election campaigns, but one congressional leader declared in 1981 that "Ronald Reagan's selection may have its most radical impact on the health care industry." This assertion may ultimately prove true, but if so it will be attributable to a transformation-and in some respects an intensification-of the federal role in health care, rather than a decided step away from federal involvement in the American health care system.

This resiliency of the federal government role in health care extends to all aspects of its relation with the nation's health care system, state and local governments, and health-related social and economic activity. This pattern encompasses federally funded and regulated categorical and block

*Assistant Professor, Health Politics, Department of Public Health Policy and Administration, School of Public Health, University of Michigan, Ann Arbor, Mich. 
grant programs in health care, as well as direct federal regulation of health care delivery and public health functions such as environmental protection. It suggests an enduring role for the central government in health policy, albeit one that increasingly emphasizes cost containment rather than service expansion or equalization.

\section{ATTEMPTING TO DEFEDERALIZE}

The Reagan strategy to defederalize American health care consisted of three general lines of attack that, if fully accepted and implemented, would indeed have shriveled the involvement of the central government in the system. Each portion of the strategy succeeded in certain respects, but, as we shall see, the overall impact was reduced by a variety of institutional, political, and philosophical factors. Nonetheless, the very emergence of such a concerted effort to defederalize American health care constituted an unprecedented challenge to a concentration of central government authority that had accumulated gradually over almost a halfcentury.

\section{DECENTRALIZATION}

One aspect of this defederalization strategy stemmed from a perception that, to the extent the public sector could play an appropriate role in health care at all, its activities should be concentrated at subnational levels of government. In particular, many politicians and policy analysts in the late 1970s and early 1980 s increasingly perceived states to be linchpins of the federal system and the logical focal point for public sector involvement in health care. The Reagan era version of decentralization. thus differed from the local government orientation of the earlier Nixon administration decentralization efforts. This transfer of authority to state governments could be accomplished through a number of legislative changes, including outright dismantling of existing federal categorical programs and consolidating multiple categoricals into broadly defined block grants that states could allocate for multiple purposes. There was no more enthusiastic proponent of this multifaceted approach to decentralization than President Reagan, who explained in 1981:

I have a dream of my own. I think block grants are only the intermediate step. I dream of the day when the federal government can substitute for [block grants] the turning back to local and state governments of the tax sources we ourselves have preempted at the federal level so that you would have those tax sources. (Cannon and Dewar 1981) 
A variety of decentralization proposals were made during the first Reagan administration, including one recommendation for a grand swap of control over various grant-in-aid and entitlement programs accompanied by tax turnbacks, that was the centerpiece of his 1982 State of the Union address (McKay 1985, pp. 183-89). All of these were consistent - with what David Walker, formerly of the U.S. Advisory Commission on Intergovernmental Relations, has characterized as "an almost wholly devolutionary approach . . to to achieving its prescribed cure of intergovernmental decongestion" (Walker 1983, p. 3). Health care programs were important components in all of these proposals, but they were not necessarily slated for the most far-reaching decentralization.

\section{DEREGULATION}

The Reagan defederalization strategy called for far more than shifting authority over programs of the central government to the states. Numerous proposals were made to weaken the capacity of federal bureaus and agencies that regulated both health care delivery and the social and economic activity which threatened public health. Health Systems Agencies and the certificate-of-need process as well as the health-related regulatory activities of such bodies as the Food and Drug Administration, the Occupational Safety and Health Administration, the Environmental Protection Agency, and the Federal Trade Commission faced a series of assaults. Vice-President Bush directed a task force charged with reversing or weakening those regulations perceived as most onerous to business and industry; individuals opposed to the basic mission of certain bureaus or agencies were appointed to leadership positions; and proposals were made to reduce dramatically funding for many organizational operations. All of these actions constituted an effort to reduce or eliminate the regulatory burden on many industries, including regulatory activity with a direct role in health care or with a direct impact on public health.

\section{DEDISTRIBUTION}

Both the decentralization and deregulation proposals had fairly lengthy periods of incubation. They were buttressed by a growing body of highly critical policy research and increasing public skepticism concerning the federal role in domestic policy that created a context in which far-reaching changes could be proposed by a popular national leader. Various decentralization proposals, calling for a shift from central to local government control, had been offered and some had been accepted during the Nixon administration, and deregulation was a popular topic dur- 
ing the Carter years. But the third aspect of the Reagan strategy was perhaps most novel and radical. Indeed, the mere mention of the idea of taking away benefits or entitlement to health care services for such politically potent constituencies as senior citizens was almost revolutionary. Governments are generally adept at creating and distributing governmental benefits, whether direct subsidies or services. The central government has no rival in the American context in this regard.

It is almost wholly inexperienced, by contrast, in "dedistributing" such benefits and services, particularly the transfer of them from politically important constituencies to such broad efforts as national defense improvement or deficit reduction (Light 1985). It is one thing, for example, to shift responsibility for a specific health care program from the federal government to state government (decentralization) or to weaken restrictions on the research and promotional activities of pharmaceutical companies (deregulation). It is another step entirely, however, to openly discuss reducing or eliminating direct forms of central government assistance to individuals through entitlement programs such as Medicare or Social Security. Although these types of alternatives were advanced more gingerly than other aspects of their defederalization strategy, various efforts of the Reagan administration attempted to legitimize serious consideration of dedistribution, whether through increasing the eligibility age for receiving Medicare and Social Security benefits or through even more radical proposals such as privatization of Social Security or transforming Medicare into a catastrophic-oriented or voucher-based program.

\section{STEPS TOWARD DEFEDERALIZATION}

The Reagan administration strategy to reduce the federal government role in health care has not been easy to adopt. Some decentralization, deregulation and dedistribution has occurred, but what is most striking about the federal system of the mid-1980s is how much it continues to resemble the system of the late 1970s. Although the first half of the 1980 s was dominated by talk of fundamental political realignment and by the seemingly inexhaustible popularity of a president with an abiding commitment to transfer authority to state governments and the private sector, the central government role in health care remains substantial.

Defederalization efforts have not been entirely sidetracked. A number of changes have occurred during the 1980s, particularly in the first half of the first Reagan term, that reduced certain aspects of the central government role and seemed to set the stage for additional alteration of the federal role in health care. Some decentralization was accomplished, 
for example, through the consolidation of numerous categorical programs, many of which were highly restrictive, into new block grants that were intended to maximize state discretion in the use of central government dollars for health-related services. These changes paralleled in many respects the decentralization efforts of the Nixon years, in which General Revenue Sharing was established and major block grants were created for employment training and community development. The number of federal categorical programs shrank from 539 in fiscal year 1980 to 404 in fiscal year 1984. Health care categoricals were not exempt from this process: 21 programs were compressed into four new block grants that received significantly less funding than the combined costs of the earlier programs. Programs that had focused on high blood pressure, risk reduction and health education, venereal disease, immunization, fluoridation, rat control, lead-based paint poisoning prevention, and family planning services, for example, were consolidated into a Preventive Health Services Block Grant.

Many of the programs that survived consolidation were altered so as to give states greater influence over their operation. States gained considerable new authority over Medicaid, as federal policy changes enabled them to contract with less expensive hospitals and physicians; limit the service choices of program recipients; reimburse hospitals differently and at lower levels than before; decide who should receive coverage under optional eligibility categories; offer various community-based services in place of nursing home care; and more easily acquire waivers to experiment with alternative methods for service delivery (Altman and Morgan 1983; Freund 1984). The central government role in Medicaid funding also declined, as the federal share of program costs was reduced by 3.0 to 4.5 percent annually between fiscal years 1982 and 1985, and more than one million people were declared ineligible for Medicaid through legislated rule changes. Moreover, some have argued that the decentralization efforts of the Reagan administration have gone so far as to have "largely broken the link between the distribution of Medicaid funds and state compliance with federal Medicaid requirements" (Mashaw and Rose-Ackerman 1984, p. 114).

Some degree of deregulation was also achieved in the early 1980s. Health Systems Agencies were rendered impotent by substantial funding cuts, halting a major experiment in central government-sponsored health planning. The Reagan administration also took full advantage of its appointment powers to stock regulatory agencies and bureaus holding healthrelated duties with officials who were devoted to the cause of deregulation. This strategy had its most dramatic impact on environmental policy with the appointment of controversial figures such as Anne Gorsuch and 
Rita Lavelle to the Environmental Protection Agency, but it also resulted in significant changes in the interpretation and enforcement of regulatory responsibilities in numerous other agencies and bureaus. The Office of Management and Budget gained unprecedented authority over the activities of health-related regulatory agencies in 1981 through Reagan's Executive Order 12291 that provided it with superagency stature and mandated cost-benefit analysis in the agencies.

Furthermore, seemingly impregnable entitlement programs of the central government such as Social Security and Medicare, which directly assist formidable political constituencies, were exposed to unprecedented dedistributive pressures. Policy change was particularly extensive in Social Security: the 1981 Omnibus Budget Reconciliation Act eliminated the minimum benefit for both new and current recipients and phased out benefits for postsecondary students 18 years or older, and the legislative package developed by the 1983 Bipartisan Commission on Social Security Reform authorized a gradual increase in the standard retirement age to 67 beginning in the year 2000 and the taxation of program benefits for high-income individuals and couples. The Medicare program escaped such extensive dedistributive changes, but both the hospital and physician deductibles were increased in 1982, among other modifications. In addition, the recommendation of the Bowen Commission on Medicare to raise the eligibility age to 67 and the mounting concern over the adequacy of the program's trust fund suggest continuing pressure for change. As R. Kent Weaver has noted, "the direction of entitlement policy choices has shifted; a long-term trend toward expanded eligibility has been reversed" (Weaver 1985, pp. 307-8). Health care entitlements were consistent with this pattern.

\section{LIMITS TO DEFEDERALIZATION}

These changes produced an American health care system that, in certain respects, was less central government-oriented but hardly transformed by the late 1980s. Despite all the forces that seemed to indicate not only health care defederalization but fundamental political realignment, the kinds of changes that have occurred are more the stuff of incrementalism than policy revolution. On the whole, relatively little shift of authority from Washington to state governments and the private sector occurred, and a number of developments suggest that the future role of the federal government in health care may stabilize or gradually increase rather than be decisively reduced. After exploring the failure to transform the federal role in health care, I shall consider the complicated set of factors 
that must converge for major shifts in policy to occur and how these factors did not converge (and are unlikely to do so) in this policy area.

\section{LIMITS TO DECENTRALIZATION}

There has been no grand transfer of authority or resources from the federal to subfederal levels of government in health care or in many other areas of domestic policy. Block grant creation, categorical program tinkering, and certain funding reductions notwithstanding, most of the major federal activities in health care have changed surprisingly little since 1980. This is consistent with the overall pattern of federal grants, since more than 80 percent of federal aid remains in categorical programs (Lovell 1985, p. 613) and the vast majority of regulatory provisions previously attached to those programs remain in force. David Beam, formerly of the U.S. Advisory Commission on Intergovernmental Relations, concludes that "the basic contours of the federal system are not markedly different. No real devolution of power has been accomplished" (Beam 1985, p. 589).

After early efforts at decentralization either trimmed, eliminated, or consolidated the most politically vulnerable and smallest health care programs, further changes proved more difficult to achieve. The health block grants encompassed fewer categorical programs, contained more funding, and featured far more regulatory restrictions than originally proposed. Many regulatory provisions normally attached to categorical programs were ultimately affixed to one or more of the new health care block grants, including "maintenance of effort" and "supplement not supplant" restrictions on funding usage, matching and reporting requirements, limits on expenditures for administrative costs, and citizen participation requirements. Although designed as vehicles for decentralization, these block grants borrowed heavily from their categorical, federally oriented predecessors.

Nor were these initial changes stepping-stones to more profound alterations of federal grants. The most ambitious decentralization strategy, the "New Federalism" proposed by Reagan, was not particularly threatening to the federal role in health care and, moreover, was politically stillborn. This proposal called for a swap of three major programs, with the federal government assuming full responsibility for Medicaid while states would take full responsibility for AFDC and food stamps. This component would actually have increased the federal role in health care, but would have been offset by a turnback to the states of some 61 federal programs as well as some of the revenues (tax sources) to pay for them. However, the proposal quickly dropped from political sight and no equally comprehensive scheme of decentralization has been forthcoming. 


\section{LIMITS TO DEREGULATION}

The deregulatory fervor that transformed telecommunications, aviation, trucking, and other industries in the late 1970s and early 1980s had little transferability to social regulation. Health Systems Agencies and Professional Standards Review Organizations were phased out, but new and more forceful central government regulatory programs emerged at the same time. The federal government terminated subsidies to Health Maintenance Organizations, but continued to evaluate those seeking federal qualification status and devised new measures to stimulate enrollment in HMOs by Medicare and Medicaid recipients. The number of HMOs deemed federally qualified soared from 42 in 1977 to 128 in 1981 to 310 in 1985 . Moreover, most aspects of social regulation linked to health remain largely unchanged. As the decade nears its end, any deregulatory momentum seems to have been reversed in favor of continued or intensified federal regulatory efforts.

Reducing regulatory competence through budget cuts and weakening commitment to regulation through appointment of officials opposed to the basic mission of their bureau or agency proved to be the principal Reagan approach to health-related deregulation. The Occupational Safety and Health Administration and the Environmental Protection Agency were particularly affected by this strategy. But, in the process, most of the legislation underlying the social regulatory activity of the federal government was never seriously challenged. Moreover, the adverse publicity attracted by some of the actions of controversial officials and the seemingly resilient public commitment to strong social and health regulatory policy triggered a political backlash that appears to have pushed serious discussion of health-related deregulation off the political agenda. Rather than being a "watershed in social regulation", this period has been characterized as "a detour on the road to regulatory reform" (Eads and Fix 1984, p. xiv).

\section{LIMITS TO DEDISTRIBUTION}

The steps toward dedistribution were profound in that they began to withdraw previously authorized federal entitlement benefits but were modest in impact. Some entitlement programs were significantly reduced during the first Reagan term, such as trade adjustment assistance, guaranteed student loans, child nutrition, and food stamps, but health care entitlements emerged relatively unscathed. During the period from 1975 to 1984 , described by $\mathrm{R}$. Kent Weaver as a time of entitlement "consolidation and retrenchment", health care entitlements continued to increase their share of the total federal budget, although at a declining rate from the prior decade (Weaver 1985). 
Overall health spending by the central government has continued. to increase since the late 1970s, driven by the growth of Medicare, Medicaid, veterans' care, and health research. It soared from $\$ 73$ billion in 1981 to $\$ 109$ billion in 1985 , well above the inflation rate during this period. Even as national defense, Social Security, and interest payments - consumed an ever growing percentage of total federal government outlays during the 1980s, the percentage of the budget devoted to health programs continued to climb. It grew from 10.1 percent in 1977 to 10.8 percent in 1981, reached a record 11.5 percent in 1985, and is expected to attain even higher levels in the late 1980s (Table 1).

TABLE 1 Health Program and Overall Federal Budget Outlays, and Health Program Outlays as Percentage of Overall Outlays, 1977-1986 (billions of current dollars)

\begin{tabular}{|c|c|c|c|c|c|c|c|c|c|c|}
\hline & 1977 & 1978 & 1979 & 1980 & 1981 & 1982 & 1983 & 1984 & 1985 & $1986^{\mathrm{a}}$ \\
\hline $\begin{array}{l}\text { Health care } \\
\text { services }\end{array}$ & 13.0 & 13.9 & 16.0 & 18.0 & 21.2 & 21.8 & 23.0 & 24.5 & 27.0 & 28.6 \\
\hline Health research & 2.5 & 2.8 & 3.0 & 3.4 & 3.8 & 3.9 & 4.0 & 4.4 & 4.9 & 5.5 \\
\hline $\begin{array}{l}\text { Education \& } \\
\text { training of } \\
\text { health care } \\
\text { work force }\end{array}$ & 1.0 & 0.9 & 0.6 & 0.7 & 0.8 & 0.7 & 0.6 & 0.4 & 0.5 & 0.5 \\
\hline $\begin{array}{l}\text { Consumer \& } \\
\text { occupational } \\
\text { health and } \\
\text { safety }\end{array}$ & 0.7 & 0.8 & 0.9 & 1.0 & 1.0 & 1.0 & 1.1 & 1.1 & 1.2 & 1.2 \\
\hline Medicare & 19.3 & 22.8 & 26.5 & 32.1 & 39.2 & 46.6 & 52.6 & 57.5 & 65.9 & 68.7 \\
\hline $\begin{array}{l}\text { Hospital and } \\
\text { medical care for } \\
\text { veterans }\end{array}$ & 4.7 & 5.3 & 5.6 & 6.5 & 7.0 & 7.5 & 8.3 & 8.9 & 9.5 & 9.9 \\
\hline $\begin{array}{l}\text { Total health } \\
\text { program } \\
\text { outlays }\end{array}$ & 41.2 & 46.5 & 52.6 & 61.7 & 73.0 & 81.5 & 89.6 & 96.8 & 109.0 & 114.4 \\
\hline $\begin{array}{l}\text { Overall budget } \\
\text { outlays }\end{array}$ & 409.2 & 458.7 & 503.5 & 590.9 & 678.2 & 745.7 & 808.3 & 851.8 & 946.3 & 979.9 \\
\hline $\begin{array}{l}\text { Health program } \\
\text { outlays as } \\
\text { percentage of } \\
\text { overall budget } \\
\text { outlays }\end{array}$ & 10.1 & 10.1 & 10.4 & 10.4 & 10.8 & 10.9 & 11.1 & 11.4 & 11.5 & 11.7 \\
\hline
\end{tabular}

Source: U.S. Office of Management and Budget, Budget of the United States Government, Fiscal Year 1987 (Washington, D.C.: Government Printing Office, 1986).

astimated outlays. 


\section{SIGNS OF REFEDERALIZATION}

Defederalization was further mitigated by a number of developments that called for a greater central government role in health care. At the very time that decentralization, deregulation, and dedistribution initiatives were moving slowly if at all through the political system, federal involvement in health care was expanded or intensified in certain respects. This refederalization of American health care constituted yet another twist on what Thomas Anton has characterized as a "gradual augmentation of national government power" that has occurred since the New Deal (Anton 1984, p. 23). Rather than simply expand federal responsibility for health care service delivery or health regulation on an incremental basis, the federal government in the 1980s latched onto a significant new tool for guiding the health care system and assumed new areas of regulatory involvement.

The most profound development was the creation of prospective payment based on Diagnosis-Related Groups (DRGs) in the Medicare program in 1983. This regulatory tool gives the federal bureaucracy, subject to congressional oversight, the authority to establish in advance rates of reimbursement for hospitals that serve Medicare patients. Rather than transfer rate-setting authority to the marketplace (as would a deregulatory strategy) or to state government (as would many decentralization strategies), the DRG process gives unprecedented authority to the central government. The Department of Health and Human Services has used DRGs as the principal component of its strategy to contain Medicare costs. That strategy eschews withdrawing benefits from recipients in favor of applying pressure on service providers to make them work more efficiently. This new tool might have been used cautiously given the general anticentral government climate and Washington's traditional reluctance to disrupt providers, but DRGs have quickly become a cornerstone of the federal health care regulatory effort. James Morone and Andrew Dunham have noted that it "is striking how quickly federal officials began squeezing DRG payments to hospitals" (Morone and Dunham 1985, p. 277).

The long-term potential of DRGs for expanding and intensifying the central government role in health care does not lie merely in its current application to hospitals under the Medicare program. Morone and Dunham even suggest that DRGs could constitute a "slouching towards national health insurance", with this approach being gradually expanded to other areas, such as Medicare physician payments, Medicaid and, conceivably, all reimbursement to hospitals and physicians (Morone and Dunham 1985, p. 277). This would be entirely consistent with the gradual, expansion of the central government role in health care over recent decades, with a new round of incrementalism launched from the starting 
point of DRGs now that the more traditional focus on expanding delivery of health care services to populations with special needs seems to have ended. DRGs may, in fact, epitomize a new form of health care regulation that involves both federal and state governments, in which regulatory approaches are designed to foster greater competition among service pro- viders while relying heavily on governmental rules to establish and governmental officials to interpret the conditions under which competition may take place. They closely resemble many of the hospital regulatory programs devised by many state governments in the past decade (Brown, forthcoming).

The advent of DRGs has been accompanied by federal sponsorship of Peer Review Organizations (PROs) to monitor the quality of care provided to Medicare beneficiaries. Rather than simply peel away the procedures established previously through Professional Standards Review Organizations in pursuit of a reduced regulatory role, the federal government has established a more rigorous peer review process whereby PROs may refuse to authorize Medicare funding for hospital services deemed unnecessary and may determine in advance whether surgical procedures are appropriate for a patient.

Other new federal government regulatory efforts in health care extend beyond Medicare. Legislation signed into law in early 1986 established new federal requirements that prevent hospitals from rejecting emergency room patients or "dumping" them on other institutions out of fear that these individuals will be unable to pay their bills. Another provision of the same legislation requires an 18-month continuation of health insurance coverage for laid-off workers in firms with 20 or more employees. It also requires a three-year extension of coverage for families of workers who die. The recipients of the extended coverage would pay the premiums, but would do so at the lower group rate. Proposals to expand these new provisions will be considered in the One Hundredth Congress.

The federal government has also expanded its involvement in a number of regulatory areas related to health. Congress has been particularly emphatic about maintaining or intensifying the rigor of national environmental legislation such as the Comprehensive Environmental Response, Compensation, and Liability Act (Superfund), the Toxic Substances Control Act, the Resource Conservation and Recovery Act, and the Clean Air Act. Such legislation is drafted with increasingly specific deadlines and requirements and is routinely exposed to detailed interpretation by the federal judiciary.

Even the Reagan administration in some instances has abetted an expansion of regulatory authority. Among those efforts related to health, the administration has sought to expand federal authority over abortion, 
care of handicapped infants, interstate transport of hazardous products, and commercial use of hazardous substances such as lead and asbestos. It has also supported legislation to link full allocation of federal highway construction funds to states' acceptance of a 21-year-old drinking age. Additional central government involvement may be forthcoming in regulation of physician fees, organ transplants, medical liability, drug abuse control, and restrictions on the tobacco industry. And, in a move almost unthinkable in an era purportedly devoted to seeking noncentral government solutions to health care and health-related problems, President Reagan in February 1987 embraced a proposal to expand Medicare to cover the "catastrophic" costs of acute illness, and members of Congress have begun to explore even more expansive program alternatives. Alongside the generally modest results of decentralization, deregulation and dedistribution efforts, these efforts to increase the central government role further deterred any shift toward a defederalized American health care system.

\section{THE IMPEDIMENTS TO DEFEDERALIZATION}

The signs of refederalization of American health care are all the more striking in contrast to the era of defederalization that appeared so likely in the early 1980s. Few periods in the twentieth century have loomed as such promising "windows of opportunity" for far-reaching change in public policy. The New Deal and Great Society were created when such windows opened, and the defederalized society envisioned by Ronald Reagan seemed within striking distance in early 1981 when he assumed office.

But policy formation, particularly when it involves major shifts of direction, is a complicated and difficult process. Analysts of this process have emphasized that various conditions must converge before policy formation can occur; a popular president with a popular message is not necessarily sufficient. Instead, political factors must augur well for new policy, ideas that are well grounded and widely accepted must be available for translation into specific policy proposals, a problem or crisis must exist to which a policy proposal can be attached and thereby legitimized, and skillful policy entrepreneurs must embrace the policy proposal and shepherd it through the formation process (Kingdon 1984). Without a convergence of such factors, policy formation is likely to be confined to tinkering with existing policies rather than making major shifts in course and taking dramatic new initiatives. In the case of the Reagan defederalization strategy, no such convergence took place. By contrast, it did 
occur in the formation of the most significant federal health care innovation of the 1980s to date, the DRG-based Prospective Payment System that may lead to an expanded central government involvement in health care.

\section{POLITICS}

The principal political force behind defederalization.was Ronald Reagan, but even his exceptional political popularity and skill were insufficient to defederalize American health policy. A president enjoys considerable authority, especially early in a term, but that authority can be extended to only so many policy priorities. And since that authority normally wanes during a term of office, those priorities must be carefully selected and adroitly pursued (Light 1982). Sensitive to these realities, Reagan emphasized tax cuts, defense spending increases, and domestic spending reductions. The last of these goals had some impact on health care, particularly through program cuts made in the 1981 Omnibus Budget Reconciliation Act, but it also inspired the search for new regulatory tools such as DRGs and PROs. Nonetheless, the defederalization strategy was generally treated as a lesser overall priority, especially as applied to health care. By the time Reagan proposed a New Federalism in his 1982 State of the Union address, he was engulfed in controversy over proposed dedistribution of Social Security benefits, beginning to slide in public opinion polls, facing a weakening economy, and about to lose his working majority in the House of Representatives. And even this sweeping proposal would have traded a reduced federal role in certain health care programs for a more dominant role in Medicaid.

Reagan remained supportive of defederalization, but more on the margins than as a central policy priority. Even after the restoration of his political popularity and his resounding reelection, Reagan did not place defederalization high on his agenda. Not only had earlier attempts in this area largely fizzled, but the president established other priorities such as income tax reform and arms reduction negotiations with the Soviet Union. He also faced a number of political setbacks, including the Iran-Contra scandal, that impaired his capacity to set the national agenda as forcefully as he had during his first term.

With less than robust political backing from the executive branch, defederalization faced formidable political opposition. One of the most important developments in American public policy in the last quartercentury has been "the relative autonomy of political institutions" (March and Olsen 1984). These institutions need not be dependent on social and political developments such as electoral support or public opinion, and 
can exercise considerable political influence, particularly in specialized areas where their expertise is unrivaled.

Whether one chooses to call the structured alliance of these institutions "subgovernments", "iron triangles", or "issue networks", they have proven to be well entrenched in federal health care policy. These health care institutions include congressional committees and subcommittees, federal and subfederal bureaucracies, and relevant pressure groups. After the policy breakthrough that facilitated the enactment of Medicare and Medicaid in 1965, "policy making in health became placid and routinized, with low public visibility and few disruptive controversies," according to Edward Laumann and his colleagues (Laumann, Knoke, and Kim 1985, p. 5). This pattern was particularly evident when these authors compared the process of policy formation in health care to the less institutionalized and more turbulent process of policy formation in energy, and it suggests that the health care policy process may be unusually resistant to significant change.

Congress proved to be a particularly formidable ally to the federal bureaucracy and pressure groups. The split-level nature of the political realignment in the 1980s left the House of Representatives in Democratic hands, assuring at least some continued commitment to the central government approaches that the Reagan administration found so unacceptable. But more important, the enduring fragmentation of congressional authority into dozens of committees and subcommittees in both chambers provided considerable protection for existing health care programs, institutions, and regulatory approaches (Davidson 1981). After committees had developed particular expertise in and influence over focused areas of health care policy, they were extremely reluctant to transform those areas and perhaps eliminate them outright. By the mid-1980s, the most influential federal policymakers in health care included congressional leaders of both parties, such as David Durenberger, John Heinz, Fortney Stark, and Henry Waxman, who used the committees and subcommittees that they chaired to offer policy alternatives that deviated significantly from those supported by the Reagan administration.

Many congressional committees minimized the impact of defederalization by accepting only those changes that were emphasized early by the Reagan administration. Granting the political imperative of cutting domestic spending in 1981, many committees used their authority under the budget reconciliation process to stretch required cuts over a large number of programs and agencies. In the process, they retained the authority to preserve most of the basic procedures and regulations for these programs. For many programs thus protected structurally in 1981 and 1982, Congress managed to restore in 1983, 1984, and 1985 some of the 
funding that had been cut and reinserted certain regulatory provisions that had been removed. The Ninety-eighth Congress proved particularly adept at using hearings to rally opposition to further cutbacks of health care programs designed to assist low-income groups.

The Reagan budget victory in 1981, therefore, was "more a triumph in his war against overall federal domestic spending than a successful strike against centralized federalism and the congressional structure that supports it" (Chubb 1985, p. 290). This was particularly true in health policy. And after Reagan's early domestic triumphs had had little impact on defederalization, the natural forces of declining presidential influence, congressional resilience to nonincremental change, Democratic gains in the 1982 and 1986 elections, and bureaucratic preferences for the prevailing order deflated any subsequent plans for decentralization, deregulation, or dedistribution in American health care.

\section{IDEAS}

The absence of ideas that were well accepted and readily transferable into viable policy proposals also undermined defederalization. Although critics of the prevailing federal order found it relatively easy to offer condemnation, they were much less effective in articulating comprehensible and politically acceptable alternatives. No clear strategy emerged that outlined the ways in which the Reagan administration intended to redirect the federal system. This was in marked contrast to the more careful idea development that guided Nixon administration efforts in redesigning federal grants and that brought issues of federalism to "a high point of conceptualization" (Palmer 1984, p. 21). Instead, defederalization Reagan-style was pursued in ad hoc fashion, using available political tools to scrape away federal authority where possible, whether trimming budgets of health care programs with the least political support or stocking regulatory agencies with officials who shared the administration's antipathy toward the existing system.

The importance of well-defined ideas in policy formation for defederalization is illustrated by the breakthroughs in federal economic deregulation that occurred in the late 1970s. Decades of research by political scientists and economists had revealed fundamental shortcomings in federal efforts to regulate various industries. This provided a solid base of ideas that legitimized radical deregulation of industries such as aviation, telecommunications, and trucking (Derthick and Quirk 1985; Page 1983). These changes had little if any impact on health care, but did illustrate that substantial defederalization was possible in which federal regulatory authority was eliminated in favor of competition. 
It proved much more difficult to chart a federal social deregulatory course for public or semipublic goods such as health care and public health protection. Whereas the deregulated market could be relied on to provide an adequate supply of telecommunication services, the outcomes of health-related deregulation were much more unpredictable and potentially dangerous for society. It remains unclear just how a deregulated health care system or environment would function, largely because few coherent ideas have emerged that would explain or guide that change. There has been extensive discussion about devising market-based strategies to facilitate social deregulation, but most proposals remain opaque at best. As George Eads and Michael Fix (1984) of the Urban Institute observed:

The problem is that no one knows what such legislation would look like. Economists have not yet met the challenge of specifying where and how their proposals could be implemented in sufficient detail to permit legislative changes to be drawn up. Neither have economists seriously addressed the ethical and political objections that have been raised to the use of market-like mechanisms. (P. 260)

And in the few instances in which such approaches have been attempted, such as emissions trading under the 'Clean Air Act, they have not performed as smoothly or effectively as theory would suggest (Liroff 1986). A number of years after federal economic deregulation has been implemented, drawing heavily on the ideas of social scientists, the ideas used to support social deregulation proposals remain too murky to be translated readily into policy.

The generation of mature ideas that would foster either decentralization or dedistribution has been similarly slow. Despite periodic discussion of a grand "sorting out" of intergovernmental responsibilities in health care and other areas of domestic policy, the analysis of intergovernmental relations and the proper distribution of authority among federal, state, and local levels of government have generally lacked any guiding theory or principles. Numerous reform proposals were developed in the late 1970 s and early 1980s, including those advanced by the National Governors Association and the U.S. Advisory Commission on Intergovernmental Relations. Many of these advocated some sort of decentralization, but none offered a compelling set of alternatives. In an exhaustive review of the research on American federalism, Thomas Anton concluded, "To the extent that recent authors have contributed anything innovative, it is a new mood of pessimism, derived from largely implicit images of despair" (Anton 1984, p. 16).

The Reagan administration was generally sympathetic to many of these decentralization proposals, but its own pronouncements on feder- 
alism lacked, according to Claude Barfield of the American Enterprise Institute, "a set of guiding principles or criteria that add up to a coherent theory of federalism". Barfield, a leading advocate of decentralization, also emphasized that the Reagan administration "has proceeded in a piecemeal fashion and has not set forth ... . its long-range goals concern.ing federalism in any detail" (Barfield 1981, p. 62). Even the New Federalism Reagan proposed in 1982 did not deviate from this pattern, as the suggested set of changes were "simply another device for reducing federal spending" rather than a coherent effort to reorient intergovernmental responsibilities according to "criteria of economic efficiency, increased accountability, administrative rationality or equity" (McKay 1985, p. 202; Peterson, Rabe, and Wong 1986, chapter 1). The proposal treated health care and welfare policy as divisible among governments, concentrating responsibility for Medicaid in Washington, D.C. and authority for dozens of other closely related programs in state governments.

The emergence of ideas based on such criteria would not, of course, automatically lead to policy formation that reflected them, since so many other factors are involved in that process. But the absence of ideas that could be reshaped into viable policy proposals limited any potential impact for decentralization or deregulation. Ideas that might shape and facilitate dedistribution were also poorly conceptualized, as little systematic thought has been devoted to the ways in which well-established central governmental benefits are best reduced.

The approach to Social Security dedistribution in 1983 may offer some lessons, in that a fairly straightforward set of options consisting primarily of different ways to reduce benefits or increase taxes had been examined, their impact was readily quantified, and they were made available to a bipartisan national commission. This body received a clear charge to do something about the program's serious funding problem and included an unusually powerful array of elected and appointed officials of the executive and legislative branches, who were allowed to forge a compromise during proceedings that were unusually secretive for the post-Watergate era (Light 1985). Although this may be a more effective method for dedistribution than simply hacking federal spending in certain programs, it does not provide a clear understanding of who deserves what from the federal government. Without coherent, well-accepted ideas to guide those decisions, dedistribution, like deregulation and decentralization, is not likely to go far.

\section{PROBLEMS}

Policy formation also requires the emergence of serious problems, often a crisis, to which ideas can be offered as a solution and around 
which political forces can coalesce. Kingdon has characterized such problems as "triggering events" that lead to a search for solutions and often result in new policy (Kingdon 1984). Just as problems of communicable disease triggered an expanded governmental role in public health in prior generations, new problems such as the alarming spread of acquired immune deficiency syndrome (AIDS) today prompt considerable governmental activity at federal, state, and local levels.

But what was the problem that would trigger an effort to defederalize American health care? The cost of health care was indeed high and growing rapidly, attributable in part to federal programs such as Medicare and Medicaid. But the very nature of the American health care system obscured many of these costs to the consumer. And while public opinion surveys showed considerable concern about the cost of health care, the American public has repeatedly demonstrated satisfaction with the care that it receives and has not perceived rising costs as a leading national problem. Opinion surveys also indicate that the public does not want any government-sponsored changes in the system to disrupt the care that is available (Blendon and Altman 1984). They further suggest that most Americans are opposed to deregulation in areas such as environmental health and dedistribution in popular programs such as Medicare and Social Security (Mitchell 1984).

It is difficult to discern any widespread perception that health care is a problem-laden area in need of extensive defederalization. In fact, since national health insurance has ceased to be a seriously considered issue, there has not been a single, attention-riveting problem in health care or federal health care policy that would trigger far-reaching defederalization. Those who bemoan "supermarbleization and hyperintergovernmentalization", deem the federal system to be "out of control" (Walker 1981) and advocate defederalization may strike a responsive chord with those who have to fill out complicated forms to obtain funding through federal programs or to comply with program regulations. Likewise, those who deem federal budget deficits to be long-term threats to economic well-being may be supportive of dedistribution. But these problems have not proved sufficient to attract extensive political support, to launch a search for policy ideas, or to culminate in far-reaching new steps in health policy formation.

To the extent that major problems or crises have emerged since 1980, they are likely to lead to greater or continued federal and subfederal authority rather than less. Insofar as policy has changed at all in response to the continuing growth of total health care costs and government budget pressures, it has involved expanded and intensified regulation at both the central and state government levels. The mounting environmental 
health concern triggered by toxic substances and hazardous wastes has put enormous pressure on legislators and regulatory officials to expand and intensify central government involvement. This problem has led to extensive state and local activity too. Furthermore, the widely publicized problems of America's poor, particularly the homeless and unemployed, have made it politically difficult to consider further reductions in federal health care and other programs that assist them. Even the leading grantsin-aid reform proposal currently on the national legislative agenda, the proposed Federalism Act of 1987 that follows the recommendations of the Committee on Federalism and National Purpose, would give the central government virtually complete responsibility for funding Medicaid, expand the scope of services and eligibility for the program, and also create a major new program in long-term care. In turn, many programs would be eliminated or consolidated, but the vast majority of these do not involve health care.

\section{POLICY ENTREPRENEURS}

A fourth component of policy formation-skillful and influential policy entrepreneurs who can pull together politics, ideas and problems into new policy - was also lacking in the case of defederalization in American health care. Whereas the formation of Medicare was attributable in part to entrepreneurs such as Lyndon Johnson and Wilbur Cohen and airline deregulation was attributable in part to the entrepreneurial talents of Alfred Kahn, no such leaders emerged to guide the various components of defederalization.

The most obvious and potentially influential entrepreneurs were too occupied with other business to champion such change. President Reagan was the most likely entrepreneur, given his long-standing opposition to a substantial central government role in health care and most areas of domestic policy. Having opposed the enactment of Medicare in the 1960s, for example, Reagan supported radical revision of the program as an offand-on presidential candidate in the 1970s. But Reagan was too devoted to the leading issues on his agenda, particularly income tax cuts and a national defense buildup, to focus consistently and intensely on health care defederalization. To the extent that domestic budget cuts became a political necessity as the budget deficit soared, Reagan was somewhat more involved. But he was never willing to risk much political capital in such an unpopular area, particularly when it came to cutting popular programs with large middle-class support, including Medicare, Veterans Administration health care, and medical research.

At the same time, those Reagan lieutenants directly responsible for 
advancing defederalization were among the least politically effective members of the administration. Potential entrepreneurs of defederalization in health care, such as cabinet-level officials and regulatory agency heads, lacked the stature and political skill necessary for the task. Department of Health and Human Services secretaries Richard Schweiker, Margaret Heckler, and Otis Bowen were not particularly influential members of the Reagan cabinet. Among leaders of health-related federal agencies and bureaus, Anne Gorsuch at EPA, Frank Young at FDA, and Thomas Auchter at OSHA had neither the political credibility nor the skill to guide a deregulation revolution. By contrast, the real policy entrepreneurs of the Reagan administration, such as James Baker and David Stockman, devoted relatively little effort to health care. As discussed earlier, the most influential entrepreneurs in federal health care policy during the 1980 s were congressional leaders of both parties who did not share the president's defederalization vision.

Policy entrepreneurship for defederalization was similarly lacking at the state level. A chorus of senators, representatives, governors, and state government associations had long railed at the strings attached to federal programs in health care and other areas of domestic policy, as well as the central government role in health-related regulation. But, with the possible exception of former Arizona Governor Bruce Babbitt, who proposed a grandiose swap of federal and state functions rather than an across-the-board reduction of federal responsibility, no particularly influential entrepreneurs emerged to steer a defederalization strategy to formation. Dedistribution was particularly unpopular once discussion shifted from generalities to specific program cuts, and state political leaderspotential entrepreneurs-were chary about staking their careers on proposals to accumulate new health program and regulatory responsibilities at their level of government. Governors played a particularly decisive role in scuttling the Reagan New Federalism proposal, deeming it to be fiscally disadvantageous to the states.

Ambitious state programs in hospital cost containment, which could ultimately be meshed with Medicare DRGs, were the biggest exception to this pattern. Indeed, the policy process that produced DRGs, initially as a Medicare demonstration project in New Jersey and later on a nationwide basis, was driven by a convergence of the very factors that were missing in defederalization. Policy entrepreneurs in state and federal governments, including legislators and bureaucrats, were skillful in transforming the basic ideas in DRG-type reimbursement into a workable policy proposal that might improve on the dismal track record of past. governmental efforts to contain costs. Officials of the New Jersey Department of Health during the Brendan Byrne administration, particularly 
Commissioner Joanne Finley, were instrumental in developing the DRG proposal and acquiring the federal agency and state legislative support needed to put it into operation.

In 1982, Congress ordered the Department of Health and Human Services through the Tax Equity and Fiscal Responsibility Act to devise a prospective Medicare reimbursement reform that responded to the mounting problem of program costs. The Health Care Financing Administration within HHS proposed a variant of the New Jersey DRG experiment that it had funded in the 1970s, and Congress acceded in remarkably short order (Morone and Dunham 1985). HHS Secretary Richard Schweiker quietly gained the support of key congressional leaders and moved the proposal quickly past a hospital industry that was divided on the issue. The House Ways and Means Committee, with the leadership of chairman Dan Rostenkowski, drafted the bill and gained full committee and House approval in one day. The Senate Finance Committee and then the Senate also approved a similar bill, which was signed by the president in April 1983, less than two months after the House action. There was minimal discussion and controversy in either chamber of Congress over this far-reaching reform, and a handful of legislators, working closely with HHS officials, were instrumental in this rapid policy formation process. In short order, the political, idea, and problem factors crucial to policy formation converged, pulled together by both elected and nonelected health care officials who demonstrated considerable political acumen and influence.

\section{RAMIFICATIONS OF REFEDERALIZATION}

The failure to defederalize American health care serves as a reminder that far-reaching institutional change is more easily said than done in American politics. It also suggests that health care occupies a distinct place on the national political agenda that may protect it from rapid policy shifts. Health care rarely emerges as the dominant domestic priority of the president or the Congress. It is unlikely that any president or major congressional leader will risk his or her reputation with an all-out effort to transform the federal role in health care, given other pressing issues. Thus, it will be rare for health care to receive the kind of political attention, and the devotion of scarce political resources, necessary to facilitate far-reaching policy change, except under very unusual conditions, such as those that led to the creation of DRGs.

At the same time, even if health care were emphasized as a highpriority agenda item, perhaps central to some future effort to slash the 
budget deficit, it retains sufficient independent prominence on the national political agenda to resist substantial change. If not such a high policy priority as to be vulnerable to far-reaching change, health care is not such a low policy priority as to be easily swept away when political currents reverse. Indeed, most areas of federal government involvement in health care retain substantial legislative, bureaucratic, pressure group, and general public support. It is not surprising, therefore, that defederalization initiatives may have had the greatest impact in those areas of domestic policy with lower standing on the national political agenda, such as housing, transportation and nonnuclear energy, and those areas within health care with the weakest political support, such as small categorical programs for the disadvantaged (Peterson, Rabe, and Wong 1986, chapter 9). By contrast, the basic components of the federal government role in health care are likely to endure given its prominent but not preeminent place on the national political agenda.

If slow to change, federal policy toward health care should not be thought of as impervious to defederalization efforts. It may, in fact, be permanently influenced by the developments of the early and mid-1980s. These can be viewed as a series of opportunities lost as well as opportunities gained.

\section{OPPORTUNITIES LOST: FAILURE TO SORT OUT THE SYSTEM}

The political mood of the early 1980s has not stimulated a thorough examination of the myriad activities of federal, state, and local governments in health care or rearranged them in a more orderly fashion. Even a clear shift of authority away from the central government is not evident. Lawrence Brown observed in 1984 that "no endorsement of devolution is sweeping American political culture" and "no orderly and principled devolution of federal activities is in prospect" (Brown 1984, p. 107). Such an assessment remains especially accurate in the context of health care policy. Where defederalization did occur it was not attributable to any careful examination of the ways in which central government resources and regulatory efforts might best be focused. Instead, defederalization advanced farthest where political opposition to change was weakest. The principal criteria for decentralizing categorical programs into new block grants was a minimum of political resistance rather than whether or not they were efficiently and effectively operated; deregulation was advanced primarily in those instances where political appointees could slow or impede regulatory activity rather than where Congress revised regulatory legislation; dedistribution was accomplished in those programs that were 
deemed politically vulnerable or for which a politically acceptable compromise could be struck rather than in those that were proven inefficacious. And, similarly, any steps toward an expanded and intensified federal government role in health care have occurred on an ad hoc basis rather than as part of any coherent strategy to redefine federal, state, and local responsibilities.

Without such a sorting out of functions, many aspects of the central government role in health care may have been cemented in, at least for the rest of this century. Many of the most pressing problems have received little attention. For example, rather than a period of sorting out responsibilities for Medicaid and more general consideration of providing health care for the indigent, the 1980s have been a period in which the federal and state governments remain at loggerheads over such matters. Neither level seems to know what to do differently, although the program has many serious shortcomings, including tremendous state-by-state disparities and huge gaps in eligibility among the lower-income population.

Future prospects for sorting out intergovernmental responsibilities for health care in a more rational way are dimmed not only by the missed opportunities of the early 1980 s but also by the fiscal realities imposed by the enormous federal budget deficits. Deficit reduction is likely to dominate the national political agenda for at least the balance of the decade, and the pressures on the central government to contain spending place it in a poor bargaining position to entice state and local governments to explore ways to reorder intergovernmental relations. State government officials scorned the Reagan New Federalism proposals, for example, when they recognized that the plan was intended primarily to transfer numerous federal program responsibilities and relatively modest revenue sources.

\section{OPPORTUNITIES GAINED: THE PRESSURE TO DEDISTRIBUTE AND THE SEARCH FOR INNOVATION}

The impact of enormous budget deficits on the federal role in health care may, however, have far greater long-run consequences than complicating efforts to sort out intergovernmental responsibilities for various aspects of health care. They may eventually place unprecedented pressure on the president and Congress to dedistribute extensively. Such pressure, whether triggered by a Gramm-Rudman-Hollings type procedure, a Constitutional amendment to balance the budget, or an economic decline attributed to the deficits, may not hit all areas of the budget equally but will certainly not bypass health care totally. And the prospect of looming $\$ 100$ billion deficits in the Medicare trust fund by the late 1990s may even 
make health care programs more vulnerable than other areas of domestic spending.

But while such pressure might ultimately open a window of opportunity to extensive dedistribution, including outright reductions in federal expenditures, it may also result in a more prudent central government role in health care. The federal government will have less money to spend, but political leaders are unlikely to extricate themselves from responsibility for popular programs such as health care for the elderly, lesspopular but enduring programs such as health care for the poor, or social regulatory activities that are designed to protect health. This will trigger a search for new procedures that will maintain the quality of existing services and the intensity of current regulations, but at a reduced cost to the federal government. In particular, this more mature federal role may emphasize reduced deference to the providers of health care services while protecting the service needs of special populations.

The DRG system for Medicare may be a prototype of the future federal role in health care. Acknowledging limits to its resources, the federal government has deployed a mechanism that gives it unprecedented leverage to set priorities-and to influence the direction-in American health care on the basis of the reimbursement levels it chooses to establish for various medical procedures. DRGs give the federal government unprecedented authority to ration health care, which has hitherto been unthinkable in the American political context (Aaron and Schwartz 1984). Already applied to hospitals that serve Medicare patients, further use of DRGs by the federal government in the future could lead to a far-reaching expansion of its role in health care. States could further increase their involvement in this process, whether through continued innovation in hospital cost-containment programs or adoption of DRGs in Medicaid. But without an exclusively state-funded health care activity that rivals Medicare in scope, and given the fact that combined state and local expenditures per capita for health are less than half of federal per capita expenditures, states will lack the leverage of the federal government in this area.

DRGs are not the only possible tool for refederalization in American health care, however. What is striking about virtually all of the major proposals for far-reaching change in health care is that they call for an extensive, and often expanded and intensified, role for the federal government. Quite aside from more traditional proposals to expand the coverage of populations with special needs, even those proposals explicitly intended to foster individual choice among service consumers and competition among service providers are heavily dependent on the federal government to determine the rules of the game. The various versions of 
the health care voucher plan proposed in the early 1980s by David Stockman and Richard Gephardt, for example, would have the federal government prescribe the number and kinds of services that would be required in a minimum health plan, and establish eligibility requirements and funding levels for vouchers. Similarly, Alain Enthoven's Consumer Choice Health Plan for universal health insurance also established a procompetitive strategy on the basis of "more intelligent use of government". Under this plan, the federal government or states under federal standards would oversee a system with open enrollment and community-rating procedures, minimum service packages, premium rates set by market area, catastrophic expense protection, and mandatory disclosure of information (Enthoven 1980, pp. 126-30). Such a system, or others like it, might indeed foster competitive efficiency and ease the pressures of dedistribution, but it would rely heavily on the regulatory skill of the federal government. Other options include prevention-oriented strategies, including new or expanded forms of health-related regulation. It is not clear, however, that any of these are likely in the short term to meet the conditions necessary for policy formation, as long as political obstacles are particularly substantial.

As the federal government searches for new mechanisms to carry out dedistribution, it will also have to address the issue of intergenerational transfer of resources. The reduction in the proportion of the elderly population below the poverty line is widely acknowledged as one of the great triumphs of programs such as Social Security and Medicare. Some have argued that this achievement has come at considerable cost to younger Americans, with public sector funding that might have been directed to the health care, education, and social welfare needs of children and young adults transferred into entitlement programs for the elderly that are indexed to the inflation rate (Preston 1984). As the Baby Boom generation matures, an extraordinary imbalance could occur with too few workers to support too many retirees while maintaining economic growth. In this situation, the federal government may have to devise new mechanisms for continuing to assist the elderly while spending less in the process. Rather than achieving a bigger or smaller federal role in health care, the ultimate challenge increasingly will be to find the most effective federal role.

\section{ACKNOWLEDGEMENTS}

I would like to thank Lawrence D. Brown, Paul E. Peterson, and two anonymous reviewers for their comments on earlier versions of this article. 


\section{REFERENCES}

Aaron, H. J., and Schwartz, W. B. (1984). The Painful Prescription: Rationing Hospital Care. Washington, D.C.: Brookings Institution.

Altman, D. E., and Morgan, D. H. (1983). "The Role of State and Local Government in Health," Health Affairs 4 (Winter): 7-31.

Anton, T. J. (1984). "Intergovernmental Change in the United States: An Assessment of the Literature." In Public Sector Performance: A Conceptual Turning Point, ed. T. C. Miller, 15-64. Baltimore: Johns Hopkins University Press.

Barfield, C. E. (1981). Rethinking Federalism: Block Grants and Federal, State and Local Responsibilities. Washington, D.C.: American Enterprise Institute for Public Policy Research.

Beam, D. R. (1985). "After New Federalism, What?" Policy Studies J. 13 (March): 584-90.

Blendon, R. J., and Altman, D. E. (1984). "Public Attitudes about Health-Care Costs: A Lesson in National Schizophrenia," New England J. of Medicine 311 (August 30): 613-16.

Brown, L. D. (1984). "The Politics of Devolution in Nixon's New Federalism." In The Changing Politics of Federal Grants, by L. D. Brown, J. W. Fossett, and K. T. Palmer, 54-107. Washington, D.C.: Brookings Institution. (forthcoming). Health Regulatory Politics. Washington, D.C.: Brookings Institution.

Cannon, L., and Dewar, H. (1981). "Reagan Asks \$48 Billion Budget Curb," Washington Post (March 10).

Chubb, J. E. (1985). "Federalism and the Bias for Centralization." In The New Direction in American Politics, eds. J. E. Chubb and P. E. Peterson, 273-306. Washington, D.C.: Brookings Institution.

Davidson, R. H. (1981). "Subcommittee Government: New Channels for Policymaking." In The New Congress, eds. T. E. Mann and N. J. Ornstein, 99-133. Washington, D.C.: American Enterprise Institute for Public Policy Research. Derthick, M., and Quirk, P. (1985). The Politics of Deregulation. Washington, D.C.: Brookings Institution.

Eads, G. C., and Fix, M. (1984). Relief of Reform? Reagan's Regulatory Dilemma. Washington, D.C.: Urban Institute.

Enthoven, A. C. (1980). Health Plan: The Only Practical Solution to the Soaring Cost of Medical Care. Reading, Mass.: Addison-Wesley.

Freund, D. A. (1984). Medicaid Reform: Four Studies of Case Management. Washington, D.C.: American Enterprise Institute for Public Policy Research.

Kingdon, J. W. (1984). Agendas, Alternatives, and Public Policies. Boston: Little, Brown.

Laumann, E. O.; Knoke, D.; and Kim, Y-H. (1985). "An Organizational Approach to State Policy Formation: A Comparative Study of Energy and Health Domains," American Sociological Review 50 (February): 1-19.

Light, P. (1982). The President's Agenda. Baltimore: Johns Hopkins University Press. 
. (1985). Artful Work: The Politics of Social Security Reform. New York: Random House.

Liroff, R. A. (1986). Reforming Air Pollution: The Toil and Trouble of EPA's Bubble. Washington, D.C.: Conservation Foundation.

Lovell, C. H. (1985). "Deregulation of State and Local Government," Policy Studies J. 13 (March): 607-15.

McKay, D. (1985). "Theory and Practice in Public Policy: The Case of the New Federalism," Political Studies 33 (June): 181-202.

March, J. G., and Olsen, J. P. (1984). "The New Institutionalism: Organizational Factors in Political Life," American Political Science Review 78 (September): 734-49.

Mashaw, J. L., and Rose-Ackerman, S. (1984). "Federalism and Regulation." In The Reagan Regulatory Strategy: An Assessment, eds. G. C. Eads and M. Fix, 111-45. Washington, D.C.: Urban Institute.

Mitchell, R. C. (1984). "Public Opinion and Environmental Politics in the 1970s and 1980s." In Environmental Policy in the 1980s: Reagan's New Agenda, eds. N. J. Vig and M. E. Kraft, 51-74. Washington, D.C.: Congressional Quarterly.

Morone, J. A., and Dunham, A. B. (1985). "Slouching Towards National Health Insurance: The New Health Care Politics," Yale J. on Regulation 2 (No. 2): 263-91.

Page, B. I. (1983). Who Gets What from Government? Berkeley: University of California Press.

Palmer, K. T. (1984). "The Evolution of Grant Policies." In The Changing Politics of Federal Grants, by L. D. Brown, J. W. Fossett, and K. T. Palmer, 5-53. Washington, D.C.: Brookings Institution.

Peterson, P. E.; Rabe, B. G.; and Wong, K. K. (1986). When Federalism Works. Washington, D.C.: Brookings Institution.

Preston, S. H. (1984). "Children and the Elderly: Divergent Paths for America's Dependents," Demography 21 (November): 435-57.

Walker, D. B. (1981). Toward a Functioning Federalism. Cambridge, Mass.: Winthrop Publishers.

(1983). "A Perspective on Intergovernmental Relations." In Intergovernmental Relations in the 1980s, ed. R. H. Leach, 1-13. New York: Marcel Dekker.

Weaver, R. K. (1985). "Controlling Entitlements." In The New Direction in American Politics, eds. J. E. Chubb and P. E. Peterson, 307-41. Washington, D.C.: Brookings Institution. 